Article

\title{
The Paradox of Water Abundance in Mato Grosso, Brazil
}

\author{
Christopher Schulz 1,2 (D) and Antonio A. R. Ioris ${ }^{3, *}$ \\ 1 School of GeoSciences, University of Edinburgh, Drummond Library G.22, Surgeon's Square, \\ Drummond Street, Edinburgh EH8 9XP, UK; P.C.Schulz@sms.ed.ac.uk \\ 2 Land Economy, Environment and Society Research Group, Scotland's Rural College (SRUC), \\ Peter Wilson Building, Nicholas Kemmer Road, Edinburgh EH9 3FH, UK \\ 3 School of Geography and Planning, Cardiff University, Glamorgan Building, King Edward VII Avenue, \\ Cardiff CF10 3WA, UK \\ * Correspondence: IorisA@cardiff.ac.uk; Tel.: +44-29-2087-4845
}

Received: 19 September 2017; Accepted: 2 October 2017; Published: 4 October 2017

\begin{abstract}
While much effort has gone into studying the causes and consequences of water scarcity, the concept of water abundance has received considerably less attention in academic literature. Here, we aim to address this gap by providing a case study on the perceptions and political implications of water abundance in the Brazilian state of Mato Grosso. Combining a political ecology perspective on contemporary water governance (empirically based on stakeholder interviews with members of the state's water sector) with an overview of the environmental history of this hydrosocial territory, we argue, first, that water abundance has become a foundational element of Mato Grosso's identity, situated in the wider context of natural resource abundance more generally and second, that water abundance today is a contested concept witnessing discursive struggles around its political implications and meaning. More specifically, there is a clash between the dominant conceptualisation of water abundance as a foundation for rich economic, ecological, social, and cultural values and benefits, often espoused by members of the political and economic elite, e.g., for marketing purposes, and a more critical but less widespread conceptualisation of water abundance as a source of carelessness, lack of awareness, and poor water governance, typically put forth by more informed technical staff of the public sector and civil society activists. By providing a distinct treatment and discussion of the concept of water abundance, our research has relevance for other water-rich regions beyond the immediate regional context.
\end{abstract}

Keywords: water abundance; water governance; political ecology; environmental history; regional identity; environmental awareness; Mato Grosso; Brazil

\section{Introduction}

Several recent studies have explored the notion of water abundance as the other side of the water scarcity coin, highlighting the political nature and practical implications of an overly simplistic understanding of this contested concept [1-5], which still remains in the shadow of the overwhelming body of literature on water scarcity (see e.g., [6-12]). Typically, the literature on water abundance is quick to dismiss the popular imagination of a state of peace and harmony that should supposedly result from abundant natural water resources $[1,3]$, pointing to the importance of developing a separate branch of critical research on the issue. Likewise, attempts have been made to unmask political uses of the concept in which discourses of (fictional) water abundance legitimise unsustainable uses of scarce water resources [5], or alternatively, to disprove claims of (mis)perceived abundance with the intention to warn against potentially detrimental policy choices that come with perceived abundance such as 
water exports [4]. On the whole, however, literature with a primary focus on water abundance remains relatively scarce.

The present paper aims at contributing to the debate on water abundance with an investigation of the concept's place in the identity of the Brazilian state of Mato Grosso, as well as in contemporary state water governance. We approach the subject from various perspectives, including a brief account of Mato Grosso's environmental history and an investigation into how the concept is employed by various actors in Mato Grosso's water governance for various political purposes today. Theoretically, we situate our research in the field of political ecology, with an emphasis on discursive and symbolic elements of political struggles over the management and governance of natural resources [13-16]. We particularly draw on Boelens et al.'s notion of 'hydrosocial territories' [14]. In this context, water abundance is thus not merely a 'natural given' but represents a discursive element employed in wider political processes of contestation. Our analysis of water abundance stands on a firm empirical basis, using quotes from interview transcripts assembled during a fieldwork campaign with 24 representatives of various stakeholder groups and organisations within Mato Grosso's water sector. We were especially interested in our interviewees' framing of water abundance to not only understand what the term means to them, but also what political consequences follow from particular interpretations of water abundance. Methodologically, we followed an exploratory 'bottom-up' approach to research, targeting as many different water-related sectors such as environmental regulation, agribusiness, fishing etc. as possible to assemble a broad sample of opinions on water governance. We believe Mato Grosso is an especially suitable case study to investigate processes of contestation around water abundance, not only because of its natural hydrological characteristics, but also because of the place that water abundance and natural resource abundance more generally has had in creating a distinct identity for this state. We thus complement our analysis of contemporary stakeholders' views with a historical overview that examines how the notion of abundance has become part of a foundational myth of the post-indigenous society in line with Boelens et al.'s theoretical approach [14].

Our paper seeks to contribute to the existing research in several ways. First, we aim to enhance the nascent literature on water abundance as a contested concept employed in political power struggles. In doing so, we shed a light on the multiple and often contradictory political implications of water abundance which demonstrate the inadequacy of the popular but limited perception of abundance as 'the solution' for water scarcity issues. Second, we aim to strengthen the case for the distinct treatment of water abundance as a subject of research by using ample empirical evidence of its importance in Mato Grosso's water governance, our case study. As we are going to show, water abundance and its discursive and symbolic use is perceived as having concrete implications on the ground and has become a short-hand reference for professionals working in the state's water sector. Third, we aim to contribute to the literature on Mato Grosso's water governance specifically and the political ecology of water in Brazil more generally, which are still underdeveloped fields of research.

Our paper is structured as follows. First, we develop our conceptual framework, situating it in the field of political ecology and complementing it with a brief overview of the literature on water abundance, providing a theoretical foundation for our paper. We then proceed with a brief overview over Mato Grosso's history and geography and its identity as a place of abundance to situate contemporary debates on water abundance within a wider context. On the one hand, this provides important background knowledge to our analysis of water professionals' views on water abundance; on the other hand, this historical overview enhances our claim that water abundance is an essential element of Mato Grosso's identity. A methodology section is then followed by a presentation and a discussion of the results of our empirical analysis of stakeholders' views on water abundance in the main part of this paper on 'the paradox of water abundance in Mato Grosso, Brazil'. Our paper concludes with an overview of the political implications of different conceptualisations of water abundance, highlighting the relevance of our findings for water abundant territories more generally. 


\section{The Political Ecology of Water Abundance}

Water is not a simple substance or resource and its allocation, use, and conservation have attracted increasing controversy, particularly in the Latin American context [13,17-21]. It is not possible to think about water in the abstract, but its properties and characteristics bear the traces of socio-political relations [22]. This calls for a more comprehensive, politico-ecological interpretation that is able to combine critical theoretical engagements with the practical experience of new movements and civil society organisations [16]. The political ecology of water is located at the intersection between the structural problems of development and of state regulation with interpersonal relations at different scales $[15,23]$. Instead of only being evident in situations of organised protest, the politics of water is also manifested in material and symbolic terms, in the daily life of the people and in the subtle forms of marginalisation and ecological degradation [24,25].

Work on political ecology, including the investigation of hydrosocial politics and water-related conflicts, has demonstrated that environmental and social change co-determine each other $[14,22]$. Instead of fixity in time or in space, the circulation of water is accompanied by an endless movement of matter and organisms in tandem with evolving social demands, practices, and discourses. Politico-ecological dilemmas related to the allocation, use and conservation of water are part and contributor to changes in the configuration of territories [26]. Water management is incorporated in processes occurring at different geographical dimensions from local demands to national development strategies. Hydrosocial territories such as catchments are spatial networks of socionatural phenomena that receive different interpretations and attract contrasting reactions depending on the academic discipline or group interest [14].

Different terminologies and conceptualisations have been proposed to capture these ideas, including "hydrosocial territories", defined as "spatial configurations of people, institutions, water flows, hydraulic technology and the biophysical environment that revolve around the control of water" [14], (p. 1), or "waterscapes" [22], which are hybrid socionatural entities and represent a departure from traditional conceptualisations of hydrology as a purely natural or technological matter. Specifically, Boelens et al. highlight the relevance of "struggles over meaning, norms, knowledge, identity, authority and discourses" [14], (p. 1) for the configuration of hydrosocial territories, which should be analysed with reference to their history, cultural features, and politics.

In the context of this literature, water abundance constitutes an important element of such hydrosocial territories that should not be seen as a mere hydrological phenomenon but rather as a connector that interrelates the natural conditions of a territory with the social processes around water management and governance, embedded in a specific historical context. Some first attempts to discuss water abundance from a political ecology perspective have been made, with a similar focus on the discursive and symbolic elements of political struggles that we aim to take in our own study [2,5]. However, the context of these studies is different as they emphasise more strongly the political component of hydrosocial territories and, in turn, give less importance to struggles around meanings and identity: Erensü limits his analysis to the small-scale hydropower sector in Turkey [2], whereas Urteaga-Crovetto analyses how transnational ethanol corporations strategically employed water abundance as a key discursive element to secure water rights and legitimise an unsustainable model of development in the Chira River Basin in Northern Peru [5]. Urteaga-Crovetto finds in her case study that water abundance is not so much a 'real' phenomenon, but is rather discursively created to suit the needs of said ethanol corporations [5], which thus tells us little about hydrosocial relations in the context of actual natural water abundance.

The same can be said about a number of publications on Canada's 'myth of water abundance' (summarised here as the only somewhat coherent body of literature on water abundance that we could identify), which mostly focus on disproving the actual existence of perceived water abundance to avert erroneous policy choices [4,27-29]. Examples are water exports to the US, overly liberal water pollution regulations, or the overuse of water resources for hydroelectric power production, when in fact, most of Canada's water resources are found in the sparsely populated north of the country and 
have comparatively low renewal rates [4]. Interestingly, Sprague repeatedly cites Brazil as 'the actual' water abundant country with the world's largest renewable freshwater resources [4], although this ignores huge regional disparities in the country [30].

Beyond the field of political ecology, water abundance has been studied in sociology [1], economics [31,32], and environmental history [33,34]. Again, however, the focus of this research is somewhat different, as Fiege's work deals with the transformation of arid lands by irrigation [34], i.e., with a form of 'artificial water abundance', and how these processes created a hybrid social and natural landscape and social order among irrigators, while Colten describes the southern US as a place of historical water abundance that is struggling to adapt to emerging scarcity due to socio-technological processes and climate change, with repercussions in the present today [33]. His analysis may potentially provide some interesting parallels to the future of Mato Grosso's water governance should it develop in a similar direction.

Tate discusses the impacts of water abundance in Canada from an economic perspective [32], arguing that it has resulted in a neglect of water demand management (as opposed to water supply management) and calls for the introduction of economic regulatory instruments such as water charges and water metres in Canadian households. Tao and Tian, in turn, relate water abundance to economic development more generally in a case study on the Chinese province of Heilongiiang and find that it may have a negative impact, as the local economy may neglect non-water related sectors and instead excessively focus on the primary sector [31].

Among the publications listed above, Alatout comes closest to a critical discussion of water abundance as a separate concept [1], beyond the immediate local context. In his study, he shows how a discourse of water abundance was used to attract Zionist settlers to the territory of present-day Israel in the 1940s, based on the popular conception of water abundance as a foundation for "a utopian world of peace and harmony" [1], (p. 383). Pointing out the relevance of a critical examination of the concept more generally, he posits that its perception as the opposite of water scarcity and a solution to environmental conflict may lead to a misguided policy focus aimed at creating conditions of abundance. For example, a water conflict would be resolved by simply increasing the amount of water available; that is, creating abundance to manage and mitigate scarcity. According to this interpretation, abundance is the opposite of scarcity and one is categorically incompatible with the other (see also [3]). However, it is important to have a more nuanced and dynamic interpretation of scarcity and abundance, which are in effect related and interdependent terms, yet not inherently linked with environmental conflict.

Our paper thus contributes to the political ecology literature by offering an empirical account of how political struggles around the meaning of water abundance are interwoven with questions concerning regional identity; by providing a more distanced analysis of water abundance that moves beyond proving or disproving the actual existence of relatively large volumes of water; and by advancing beyond the question of whether water abundance prevents (violent) conflict or not, instead shedding a light on the ways in which the concept is invoked discursively in the regional water governance context and on its political implications.

Regarding the status of this paper in relation to the literature on Brazilian water governance literature, there are no obvious connections to previous research, beyond a very brief remark by Veiga and Magrini that "[for] a long time the notion of quantitative abundance supported a culture of water wastefulness and postponement of investments necessary for more efficient use and protection of water resources" [30], (p. 2292). However, Veiga and Magrini do not specify where exactly this abundance occurs, considering the unequal distribution of water resources in the country [30]. The principal focus of interest of this literature has instead been the implementation of Brazil's 1997 water law (Law 9.433) (see e.g., [17,18,35-39]), which brought about major changes in water governance, including the introduction of river basins as the primary management unit, the creation of river basin committees, and the use of economic governance instruments such as bulk water charges. Despite the ambitious nature of this reform, political ecologists and other critical researchers argue that the supposed change 
was not meaningful and represents a mere switch in 'technologies of government', as existing power asymmetries are reproduced within the new institutional framework $[17,18,38,39]$.

While such literature aims at contrasting water governance 'on paper' with the deficiencies of (and inequities within) actual water governance, our approach here is different; we aim to study the role and status of water abundance more generally in Mato Grosso's water governance, which transcends individual laws that are more often than not implemented. In doing so, we also aim to contribute to the literature on Mato Grosso's water governance from a social science perspective, as the topic is currently studied mostly from more technical viewpoints, e.g., investigating flood control mechanisms [40], water quality [41,42], the impact of hydroelectric power facilities [43,44], and its legal and institutional framework [45], or has a more narrow regional focus on the Pantanal wetland $[46,47]$.

\section{Mato Grosso and the Promise of (Water) Abundance}

In the early phase of colonisation, in the Seventeenth Century, the economy of Mato Grosso was intimately associated with territorial expansion and the advance of an idiosyncratic form of exploratory and mercantile capitalism that relied on the exploitation of landscape resources [48-50]. The Iberian influence in Mato Grosso began in the early Sixteenth Century-it is worth mentioning the extraordinary journey of Cabeza de Vaca through South America between 1528 and 1537-when the first Europeans, including missionary Jesuits, introduced cattle to the region in order to benefit from the extensive pastures and abundant water of the Pantanal [51].

Cattle adapted relatively well to the local conditions, characterised by seasonal floods that help to fertilise the fields. Moreover, while the Spaniards arrived first, they did not colonise the region, and the early settlements established in the Pantanal were soon abandoned. Mato Grosso, like other parts of present day Brazil, was explored by expeditions of Luso-Brazilians coming mainly from São Paulo, known as bandeiras (literally, flags), in search of indigenous slaves and precious metals and stones. The leaders of these expeditions, known as bandeirantes (trailblazers), had a reputation for being both brave and violent, and they gradually grew to become highly celebrated figures in the popular imagination $[48,49]$.

Gold extraction in Mato Grosso commenced in the second decade of the Eighteenth Century in the area around Cuiabá, a town that was founded by the Portuguese crown in 1726 [50]. The 1750 Madrid Treaty, agreed between Portugal and Spain, resolved the two countries' long territorial dispute with the recognition of the rights of Lisbon over most of the Amazon and the west of Brazilian colonial territory. While better integration of the different parts of Brazil was a recurrent goal, although difficult to attain, it was not true, as claimed by the official historiography, that Mato Grosso was almost completely isolated from the rest of the country. On the contrary, the territory of Mato Grosso was strategically important to the colonial, and later national, economy because of its mines and localised commercial centres.

The combined myth of isolation and natural resource abundance has, in effect, served to boost the heroic image of conquest and to reinforce the claim that the remote corners in the centre-south of Brazil owe much to the bravery of São Paulo's bandeirantes. In order to facilitate access to the province, an agreement was signed with the Paraguayan Republic in 1856 regarding permission to navigate the Paraguay River system. International river navigation in the centre of South America was also a British geopolitical demand and part of the country's imperialist and trade expansion plans. This directly affected the interests of Paraguay, which was at that time the most industrialised and aggressive country in the region.

The long, bloody, and large-scale Paraguay War, between 1864 and 1870, began with the occupation of the southern half of Mato Grosso and was largely associated with the control of fluvial navigation [46,52]. During the conflict, which was the most ferocious in the history of the South American continent, local farmers were forced to supply the troops with meat and leather. The regional economy was decimated and the small number of cattle that survived ended up dispersed and unmanaged. It took some years for settlers to gradually return and for farms and fluvial navigation to slowly recover. 
Strong patrimonialism and widespread corruption facilitated the formation of an unproductive elite in charge of provincial administration and overseeing the extraction of natural resources such as timber, rubber and minerals, which continued after the proclamation of the republic and end of the monarchy in 1889 [50]. Society leaders in Mato Grosso not only controlled the allocation of regional resources (with the tacit acquiescence of the absent and distant national government) but also systematically tried to redefine its identity with a peculiar combination of the stereotypes of territorial conquest and the supposed valour of both white and non-white groups that formed the basis of regional society.

In the early 1900s, references to the bandeirantes as heroes of national expansion were still common, reinforced by the work of the History Institute of Mato Grosso, created in 1919. Local writers such as the famous archbishop and state governor Aquino Correia persistently tried to subvert the common feeling of backwardness with claims about the racial purity of the (idealised) American Indians and the pioneer spirit of the regional population [49]. At the same time, Mato Grosso retained its attractiveness for cattle ranchers, who generally perceived the area as a place of water abundance, which, in addition the availability of land, was seen as the most important factor serving as a basis for the local economy [53].

History and geography took a new turn after the 1930 political coup (Revolução de 1930), which deposed the elected president and installed Getúlio Vargas as the new national leader. The 1930 Revolution is considered a milestone in the evolution of Brazilian capitalism as it led to the acceleration of industrial production and urban growth. It was a nationalistic phase characterised by political centralisation and the concentration of power in the hands of federal authorities at the expense of regional oligarchies. The president-dictator Getúlio Vargas famously launched the 'March towards the West' (Marcha para o Oeste) as a coordinated set of policies for economic development of the hinterland [49].

Regional development strategies and programmes were permeated by the ideology of national integration and the alleged need to 'occupy' empty spaces (considered vast wastelands) [54]. The experience with coffee production in the southeast of the country had already demonstrated that agricultural frontiers in Brazil are typically promoted by the national state, creating border zones with plenty of money-making opportunities, although, in practice, only a small number of farmers, traders and politicians really benefitted from the new agrarian economy. A similar process occurred under the influence of the 'March towards the West' and involved a series of initiatives that were defended as important contributions and necessary enterprise for the modernisation of the economy and the affirmation of national sovereignty [55]. The western hinterland was simultaneously perceived as a challenge and a paradise, a vast terrain rich in resources and a concrete opportunity to realise the bright future that the country absolutely deserved $[49,56]$.

Mato Grosso's more recent history has mostly been characterised by the growth of the agribusiness sector and the arrival of many immigrants from the south of the country. After a period of turbulence and instability in the late 1980s and early 1990s [57], soybean and a few other crops expanded significantly due to a shift in government policy from supporting the industrialisation of the economy towards reprimarisation in the 1980s, e.g., due to the government providing economic incentives for agricultural exports $[58,59]$ and, in particular, the growing and consistent demand for soybean by the Chinese [60,61].

This renewed focus on the primary sector is in line with much of Mato Grosso's earlier history. As we aim to have shown in this brief overview, water abundance and natural resource abundance more generally have played a crucial part in the public imagination and perception of this territory since it was first reached by early European explorers in the Sixteenth Century. This myth of abundance was first created among those foreign explorers and communicated to the inhabitants of the more densely populated areas in the coastal regions of Brazil but remained in the state of Mato Grosso upon its settlement by external groups who evidently displaced the native indigenous tribes and groups of squatters [50]. Some parallels can be drawn with the history and present of other water-rich territories in the continent of America; for example, Canada, where natural resource abundance has been a driver 
of settlement and the creation of a national identity, while at the same acting as an impediment to the development of a more diversified economy [27].

Several major rivers that are part of Brazil's and South America's main hydrographic areas originate in Mato Grosso. These are, among others, the Paraguay, Cuiabá and São Lourenço Rivers to the South, which are part of the Paraguay and wider Plata hydrographic areas $\left(176,800 \mathrm{~km}^{2} ; 19.6 \%\right.$ of Mato Grosso's territory); the Araguaia River and Rio das Mortes to the East, which are part of the Araguaia-Tocantins hydrographic area $\left(132,238 \mathrm{~km}^{2} ; 14.7 \%\right.$ of Mato Grosso's territory); and the Guaporé, Aripuanã, Juruena, Teles Pires, and Xingu Rivers to the North, which are part of the Amazon hydrographic area (592,382 km²; 65.7\% of Mato Grosso's territory) [62], (p. 29), making Mato Grosso a net water exporting state within Brazil. The average annual precipitation ranges from $1000 \mathrm{~mm}$ to $2500 \mathrm{~mm}$ and is highest in the Amazonian part of Mato Grosso [62], (p. 34). The volume of Mato Grosso's groundwater resources has been estimated at 7,889.676 $\times 10^{9} \mathrm{~m}^{3}$, but further research is needed to improve the reliability of data on groundwater [62], (p. 43). In most areas of Mato Grosso, water demand does not exceed $5 \%$ of the water supply, with the supply thus outweighing demand by far [62], (p. 52).

\section{Methodology}

Methodologically, our study of the contemporary perceptions and political implications of water abundance followed an empirical, exploratory, and 'bottom-up' approach that involved 24 semi-structured interviews with members of different water-related sectors in Mato Grosso, carried out between October and December 2014. It was embedded in a wider exploratory study that aimed to identify the current status of water governance in the state more generally. Given that water governance (and water abundance) are rather broad topics, we targeted a wide variety of water users, including representatives from the state government of Mato Grosso, academia, the tourism sector, the fishing sector, the capital city Cuiabá's urban water supply sector, the agribusiness sector, civil society, NGOs, navigation and logistics, and consumer protection In Mato Grosso and Brazil, there are public consumer protection agencies that deal, among other issues, with complaints about water supply and sanitation. Within these sectors, we interviewed professionals with a wide range of backgrounds as well, ranging from subsistence fishermen in the Pantanal wetland to technical staff to a member of the state government. Some of the interviewees represented more than one sector, e.g., those who had changed careers or who worked in multiple sectors simultaneously.

Most interviews (18) were carried out in Mato Grosso's capital, Cuiabá, where most sectors are represented with professional associations. They were complemented with a number of interviews in rural areas in and around Cáceres in the Pantanal. For the identification of the interviewees, we partly relied on personal contacts and snowball sampling and partly on contacting organisations without any prior connections. Some interviewees were members of river basin committees, however, this was not our selection criterion, especially considering the fact that these institutions have been set up in the state only very recently and have had a limited impact in the state [36]. Rather, we aimed to interview representatives from as many different sectors as possible to capture the full range of perspectives on water governance in the state, while at the same time being fully aware that we cannot claim 'representativeness' in a statistical sense of the term. The only major omission among the water-related sectors covered in this study is the hydroelectric power sector, a representative of which cancelled an interview citing legal concerns. To protect the anonymity of our interviewees, we do not list the names of their organisations, except where it is unavoidable as we do not want to cause any (potentially negative) repercussions to interviewees whose opinions might not necessarily reflect the official communication guidelines of their organisation.

Their views on the role of water abundance were embedded in discussions of water governance in the state and the importance of rivers, the Pantanal wetland, and water resources for the area more widely, as well as of a number of concrete topics that were selected depending on the profile of the interviewee, including (1) the pollution, sedimentation and water quality of rivers; (2) urban water 
supply and sanitation; (3) water charges, river basin committees and the institutional framework of water governance; (4) changes in the flow regime and ecosystem associated with large infrastructure projects; (5) and fishing and tourism. These topics had been identified beforehand as relevant to the local water management context based on the available literature $[40,42,44-46,62-66]$ and on consultations with local academics. However, given the nature of semi-structured interviews, the interviews may have included discussions of additional topics if these were deemed relevant during the conversation.

All interviews were recorded, transcribed, and then analysed with content analysis software (Discourse Network Analyser, DNA; for an overview see [67]) to identify common argumentative categories or topics within the interview material. For example, all statements on water abundance were highlighted and extracted into one list, with additional information on the interviewee's profile such as their name and organisation. This in fact represents a very limited use of the DNA software, which was originally developed for the quantitative analysis of so-called 'discourse networks'; we employed it instead because of its ease of use, free access, and good functionality for our research purposes. Further categories concerned different aspects of Mato Grosso's water governance; for example the pollution of rivers with sewage or the importance of water resources for the history and culture of the state. Again, all statements identified as falling into these categories were highlighted in the interview transcripts and then, through the software, listed in a separate file, which allowed us to compare statements of different interviewees and to select quotes to be used in our analysis (following below).

\section{Mato Grosso's Paradox of Water Abundance}

Following our argument that the concept of (water) abundance has become a foundational element for Mato Grosso's identity, explained through its historic perception as a remote place with rich natural resources waiting to be exploited, we now turn our attention to contemporary perceptions of the concept of water abundance and its place in Mato Grosso's water governance. Foreclosing some of the conclusions of our analysis, we do so within a conceptual framework that views water abundance, not as a simple hydrological phenomenon, but as a contested concept that is the subject of discursive struggles around its meaning. This is in line with much of the political ecology literature presented earlier, especially Boelens et al.'s proposition of 'hydrosocial territories' that concern the intersection between the hydrological and the social realms [14].

Specifically, we found two major conceptualisations of water abundance among the responses of our interviewees: one of water abundance as the foundation for rich economic, ecological, and cultural water values and benefits (the more dominant conceptualisation) and one of water abundance as the source of carelessness, neglect of water resources, and weak water governance (a widespread but minority view). These are presented and discussed more in detail in the following paragraphs.

The first conceptualisation of water abundance as a source of rich water values is straightforward (see $[23,68,69]$ for an overview of the concept of 'water values') and was expressed in most interviews, for example among members of the agribusiness or tourism sectors:

"Water is fundamental, we need a lot, from the production of fruit to fishing, which is very common here, and tourism which is growing a lot. I can't tell you it is irrelevant-it is extremely relevant. It is one of the factors that contributed quite a lot to the diversity that Mato Grosso has. Here we have a little bit of everything. We have the touristic aspect, we have the agricultural part, and we have the part of the forest, too, [it is] very broad."

(Interviewee number 23; Technical Staff Member of an Agribusiness Association)—quote 1

"Yes, everything is related with (the) water, survival itself, and fish, a source of food which is taken from the rivers, there is a large abundance, too, as for now."

(Interviewee number 7; Senior Member of a Tourist Guides' Association)—quote 2 
"The river is fundamental, the tourism that we have today, it is all related to the Paraguay River, thanks to the Paraguay River we have tourism down here."

(Interviewee number 12; Hotel Owner, Pantanal)—quote 3

These quotes are representative of a much larger number of quotes on the multiple values and benefits that Mato Grosso's rivers and water resources provide to its population, and the notion of water's fundamental importance for this hydrosocial territory was echoed by almost all interviewees. Not all interviewees would explicitly reference the concept of water abundance, but it was implicitly present in almost all conversations, e.g., as in quote 1 . To some extent, it is not surprising that professionals from water-related sectors would allocate such a prominent position to water resources in the state; due to its very nature, water is hardly irrelevant anywhere in the world and people in water-related sectors would be the first to acknowledge this. However, in Mato Grosso, water abundance has attained a special status that is seen as one of the primary character-giving elements of this hydrosocial territory as is exemplified by government-sponsored campaigns to brand the state as "The State of the Waters" (O Estado das Águas), which can be found e.g., in the then environmental secretary of state's invitation to a national river basin committee conference in 2012 [70]. This type of branding or marketing mirrors other Brazilian states' attempts at branding, e.g., Acre's self-characterisation as Florestania ("the state of the forests"), which seeks to portray Acre as a particularly environmentally friendly state [71].

By branding Mato Grosso as 'The State of the Waters', the status of water resources in other states of Brazil is implicitly downplayed. After all, if every state branded itself as 'the state of the waters', the branding would be rendered meaningless. This is further evidence that, in terms of the first conceptualisation of water abundance that we identified empirically, it is seen as a positive element that not only serves as a foundation for the water values mentioned but simultaneously becomes a symbol for the 'distinctness' and identity of the state. De Arruda Filho justifies this special status with progress made in the early introduction of water laws [70]; indeed, Mato Grosso introduced a state water law relatively early in 1997, which mirrored the content of a federal water law in the same year [72], although their implementation is a different matter. Furthermore, he cites the fact that several of Brazil's and South America's major rivers (partly) originate in Mato Grosso, including the Cuiabá and Paraguay Rivers as part of the La Plata Basin to the south of the state, the Teles Pires, Juruena, and Xingu Rivers as part of the Amazon Basin to the north, and the Araguaia River as part of the Araguaia-Tocantins Basin to the east. This reasoning was shared by an interviewee representing the environmental NGO sector, who concluded that Mato Grosso's share in all these major river basins makes it "Brazil's and Latin America's 'water tank'" (Interviewee number 18; Environmental NGO representative), not least also because of the role of the Paraguay River and its tributaries in recharging the Guaraní Aquifer, one of the largest of its kind in South America [73].

In addition to mentioning the economic and social values resulting from abundant water resources, the interviewees complemented this conceptualisation of water abundance with statements on the less tangible cultural and historical values of the state's water resources:

"There is a use of the Cuiabá River beyond environmental questions [ ... ]. The population has an intense relationship with the use, with the water of the Cuiaba River, because, culturally, mainly the riparian population has the river as its reference point, its identity. [...] There are the festivals of the saints, which all have the river as their reference points, [ ... ] so there is the cultural question, the dances, everything that happens among those that live in the riparian areas."

(Interviewee number 2; University Researcher)—quote 4 
"The city [Cuiabá], it begins with the river. The first ships, these foreigners arrived here through the river, navigating. So, this is where all the communication and all the resources came from, the provisions and objects that the people needed here in the city. So, this is the first point and we know, through the geography as well, that the city begins [... ] at the shores of a river."

(Interviewee number 14; Civil Society Activist)—quote 5

These quotes connect well to the idea that water abundance is not only a genuinely positive phenomenon in the 'peace and harmony sense' that Alatout sought to criticise [1], but that it also has its place in creating a unique identity and culture for Mato Grosso more generally. Some evidence of this is the description of traditional festivals and even dances that are intimately linked to the region's rivers; these have been described in more detail in [74,75]. Quote 5, in turn, complements our own historical account presented earlier; not only is Mato Grosso a place of (water) abundance, but without abundance (in the form of its rivers), it could not have been colonised. The (post-indigenous) society of Mato Grosso in its present form would not exist.

This conceptualisation of water abundance in the sense described in the previous quotes is fairly straightforward as it is very close to the public imagination of water abundance as the foundation for multiple social and economic benefits, as well as for rich ecosystems. It could thus be expected that this represents the dominant narrative or conceptualisation of water abundance in the state.

However, a second conceptualisation of water abundance could be identified, with a much more negative undertone, which gave the title to this article, of the 'paradox of water abundance'. According to this conceptualisation, water abundance is in fact to blame for many water governance failures, as it induces a state of carelessness among the general population and politicians alike and causes water governance to be absent, not a political priority, poorly coordinated and implemented, or crisis-driven. It was typically expressed in statements such as the following and was more prevalent among members of the public sector, including the environment agency, Cuiabá's urban water supply sector, and university researchers, as well as civil society activists:

"The state of Mato Grosso is a state which is densely drained by many rivers; it has a large volume of surface and groundwater. But because here [in the capital region of Cuiabá] we have the largest concentration of people, that's why we have [water] stress. This stress isn't caused by a lack of water, I told you: it is a lack of investment in the [supply] network, new [water] abstractions, new systems. Here we are lacking infrastructural works to deliver this water and to treat this water. This is what is missing. We have this privilege, yes, [but] that's why [we have] this story: 'What are you worried about? We have a lot of water!'"

(Interviewee number 3; Senior Technical Staff Member in the Secretariat for the Environment)

-quote 6

The lack of investment in urban water infrastructure in the metropolitan region of the state capital Cuiabá was described in much more detail by further interviewees, who also cited the problems created by intermittent water supply, the poor administration of funds to be used for investment in water infrastructure, the pollution of rivers caused by a lacking sanitation system, mismanagement in Cuiabá's water company, the widespread installation of illegal water pipes to steal water from the city's system, and more. It should also be noted that domestic water supply and sanitation are primarily municipal responsibilities, despite their wide-ranging environmental impacts and that little coordination with the Secretariat for the Environment occurs, for example regarding the pollution of rivers with sewage.

To give some context to the above statement, in Cuiabá, the highest number of complaints with the public consumer protection agency Procon in 2014 (i.e., prior to our fieldwork) concerned domestic water supply by the local water company CAB [76], which was first privatised in 2012, with the promise of providing a better service and coupled to the condition to provide universal access to water in the capital until 2015, which, according to the regulating agency, did not occur. It was thus accused 
of breaching its contract with the municipality of Cuiabá, while the owner had to declare bankruptcy and $C A B$ had to be sold as part of the insolvency proceedings [77]. As of November 2016, a new company (Águas de Cuiabá) has taken over from CAB [78]; whether water supply and sanitation will indeed improve remains to be seen, and the construction of further sewage treatment plants to address one of the city's most pressing water issues has not yet begun.

One of the interviewees mentioned that federal funds had been allocated for the expansion of sewage treatment levels even before the privatisation which would have greatly improved the water supply and sanitation, potentially reaching a treatment rate of $70 \%$. However, these funds were never used as the municipal and state governments refused to cooperate with each other, given the political rivalry between their leaders who were of different parties. One interviewee also highlighted that conflicts around illegal water pipes (or gatos de água as they are locally known) often turn violent, "with a risk for life, with fights and clashes" (Interviewee number 2; Former Senior Staff Member of Cuiabá's Water Company), and are not restricted to marginalised neighbourhoods but concern affluent areas as well, which were described as having little concern for the legality of their water supply.

This carelessness or lack of awareness for the importance of good water management and governance is typically attributed to Mato Grosso's status as a place of abundant water. This is best expressed in the following quote from a civil society activist, who reflected on the experiences of developing a water saving technology and spreading it among members of the local community in Cuiabá:

"Here in Mato Grosso, there is a difficulty, that the people, even when we began our work here, about saving water, the people, friends who came to our house, they complained, they criticised us saying: 'Gosh, you are crazy! Doing a project like this, saving water, with all the water that we have here in the Cuiabá River'. Later I found out that Mato Grosso is a state with excessive water; if you compare it with other regions of Brazil, it is a state considered to be 'the state of the waters'. So, if you want to recycle water in a state with so much water, it is counterintuitive, it is a waste of time, let's call it that way. So at the time, we were criticised because of that, because water was there in abundance."

(Interviewee number 14; Civil Society Activist)—quote 7

The logical conclusion of such a narrative, which creates a causal chain from water abundance to a lack of mobilisation and awareness of good water governance, is then a call for awareness creation, especially among politicians and members of the general public. In this view these two groups are to blame for the problems facing the state's water sector, caused by their simplistic mind-set expressed in statements such as 'there is no problem with water here', i.e., missing the point that water governance problems may extend beyond the mere availability of raw water. This reasoning is best expressed in statements such as the following:

"With regard to the water resources policies in the state of Mato Grosso [ . . ] they aren't sufficiently publicised. Because today we are within the structure of the State Secretariat for the Environment and maybe because of this lack of recognition, of major transparency in our actions, the secretariat is seen in relation to deforestation, in relation to fire, and in relation to fishing, so these are the biggest demands and no one knows what the superintendence for water resources does; who develops the water resources policies in the state isn't well-known. [ ... ] So what is missing, in fact, is that we make our work known, that the state makes it known to get closer to society, really make the importance of water resources for the lives of all of us known."

(Interviewee number 3; Senior Technical Staff Member in the Secretariat for the Environment) 
"The biggest problem, the biggest conflict in Mato Grosso is the abundance of water. So creating awareness in this society, for the issue of water resources, is still very difficult, to conquer the heart of that person, for this [...] with the people who come from outside, that come with this imagination of the 'Eldorado', the future is here, it is here where I will cut the forest, it is here that I will plant, it is here where I will make things happen, etc."

(Interviewee number 6; Senior Technical Staff Member in the Secretariat for the Environment)

-quote 9

Similar to the civil society activist (of quote 7), who went on to describe their attempts at publicising their work more widely in the media to spread awareness for water issues, these senior technical staff members claim that enhancing awareness is the only route forwards towards addressing the negative consequences of water abundance. While, to some extent, such statements could be interpreted as shifting responsibility for persisting water issues towards other actors, the conviction that water abundance was 'to blame' was remarkably widespread. In this sense, the situation is different from that in Canada where, although we do see similar discourses on the need to spread more awareness for water governance $[4,29,32]$, these instead blame people's ignorance about the actual lack of abundance. Interestingly, one interviewee (number 15; Civil Society Activist) related the wastefulness among traditional fishermen (he told an anecdote about how they would feed fish to their pigs) to Mato Grosso's status as a place of abundance. As we already argued in our historical overview earlier, abundance has become an integral part of the state's identity, but from this perspective, this includes the negative consequences of lacking concern for the protection of its resources, as described in the second conceptualisation of abundance.

Figure 1 summarises the tensions between the two opposing perspectives on water abundance in the state, which can be interpreted as elements in the wider discursive and symbolical struggles in local water politics:

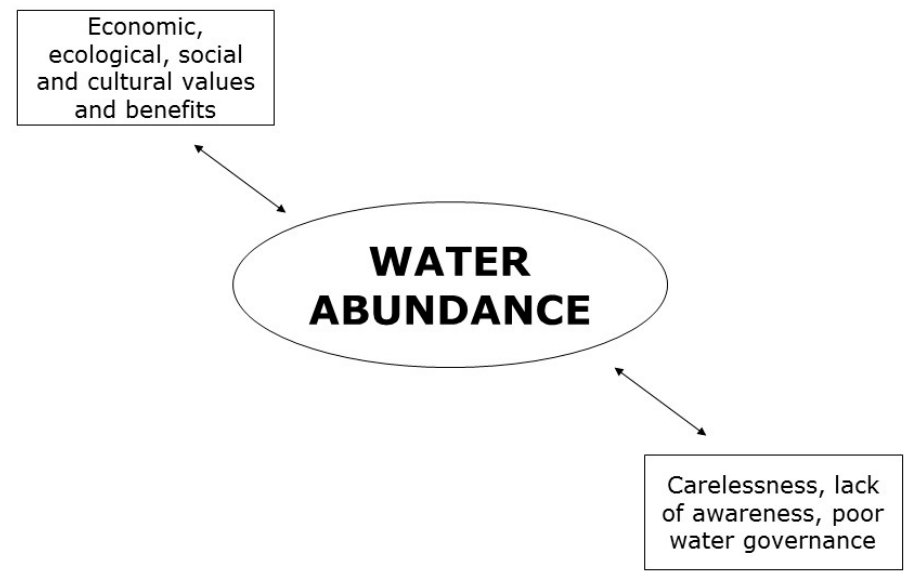

Figure 1. Competing conceptualisations of water abundance in Mato Grosso.

From a political (or critical) point of view, the first conceptualisation benefits the state government as well as economic elites. As outlined earlier, it is not only foundational for Mato Grosso's regional identity, but also can be exploited for marketing purposes by political and economic actors alike. As both government and major economic sectors such as the agribusiness sector often struggle to maintain a positive public perception locally, nationally, and internationally [79], references to the benefits of Mato Grosso's water abundance may serve them in improving their public image, a strategy also noted by interviewee no. 6 from the Secretariat of the Environment. However, these references are usually quite superficial, and mirror what Alatout has termed the simplistic perception of water abundance as the basis for "a utopian world of harmony and peace" [1], (p. 383). 
The second conceptualisation, however, is interesting in the sense that it is typically espoused by members of the core of Mato Grosso's water sector, who are very familiar with, if not actively shaping, local water governance. On the one hand, it serves as a subversive discursive strategy that aims at undermining the dominant perception of abundant water as a boon. For water professionals defending this narrative, it may also serve to explain or justify the fact that water governance is far from optimal in the state, despite their best efforts. It could also be seen as a strategy to support requests for further public resources for their work. On the other hand, this framing of water abundance carries a risk of shifting the responsibility for water management failures to natural factors, even though there is no reason to believe that natural water abundance per se renders good water governance impossible.

\section{Conclusions}

In this paper, we sought to contribute to the nascent political ecology literature on the contested concept of water abundance, using water governance in the state of Mato Grosso, Brazil, as our case study. Our analysis consisted of an empirical study with members of water-related sectors in this area and was complemented with a historical overview of how the concept of abundance has been crucial in the development of the separate regional identity of this 'hydrosocial territory' [14]. Specifically, we claim that water abundance has been an integral part of Mato Grosso's identity historically and is today, and that it is a contested concept with opposing conceptualisations that are defended by different political actors. On the one hand, water abundance is framed as the foundation for rich water values, which consist of various economic, ecological, social, and cultural values and benefits to the local society such as its role in agriculture, the maintenance of the Pantanal and Amazon ecosystems, or the importance of rivers for traditional festivities. This simplistic conceptualisation is the most common one and is often used to legitimise activities that benefit political and economic elites such as large-scale agriculture or the widespread implementation of hydroelectric power schemes.

On the other hand, water abundance is described as a source of conflict among members of the water sector, as it allegedly contributes to a state of carelessness and lack of awareness for the importance of good water governance and investment in water infrastructure, given the simplistic understanding that 'water cannot be a problem' in an area with abundant natural water resources. This reasoning confuses the availability of raw water with the availability of treated water for domestic use and also obscures the fact that water is not perpetually abundant in Mato Grosso, as for example navigation in the state's Paraguay River is impossible for major ships during the dry season [80]. This more critical perspective is typically expressed by experienced members at the core of Mato Grosso's water sector who may use it to defend the persistent existence of water management failures such as low rates of sewage treatment and the associated pollution of major rivers or the poor administration of Mato Grosso's capital city Cuiabá's water supply, despite their best efforts to mitigate these issues. The main consequence of this conceptualisation would then be that awareness for good water governance should be raised, e.g., through better information and education.

However, such a narrative does not come without its risks, as it may be employed as an easy strategy to eliminate responsibility for management failures from the water sector and shift it to non-human factors, i.e., the physical presence of large volumes of water in the state. One may also question whether water management problems in Mato Grosso may not, in fact, reflect wider systemic issues that plague public administration in Brazil more generally, such as corruption, excessive bureaucracy, the subordination of public interests to private interests, and low compliance with laws $[81,82]$ and whether using water abundance as a short-hand reference may crowd out such alternative explanations.

Stepping back from a discussion of the specificities of Mato Grosso's water sector, our research opens up questions for further research on the role of water abundance in other areas of the globe; specifically, it would be worthwhile to study other water-rich areas and to examine whether they too experience such discursive clashes on the meaning and implications of water abundance. There is some evidence from Canada and the challenges local water professionals face there in dispelling 
a persistent 'myth of water abundance' among politicians, the media and members of the general public that points in a similar direction [4,27-29]. However, the subject of discussion and processes of contestation in the Canadian water sector are not so much the consequences of raw water abundance as in Mato Grosso but rather the consequences of perceived water abundance, where it is, in fact, absent. With climate projections predicting a decrease in rainfall and a much drier climate for Mato Grosso in the coming decades [83], the state may face a similar challenge to dispel the widespread perception of unlimited water resources in the future. As we have shown in our case study, water abundance is neither 'the solution' to water scarcity problems, as water abundance does not translate into an absence of conflicts [1], nor is it a neutral concept [84], and the way it is employed by political actors lends itself to various political purposes that can be identified and discussed in empirical research. While many researchers have dedicated their efforts to analysing water scarcity from such a critical perspective, water abundance is a disputed and contested concept in its own right that needs critical investigation in different local contexts.

Acknowledgments: The research was funded by a Scottish Government Hydro Nation Scholarship. The authors would like to thank all the stakeholders who agreed to be interviewed for this research. Further thanks go to Peter Zeilhofer and Eliana Dores at the Federal University of Mato Grosso (UFMT) for hosting Christopher Schulz during the fieldwork for this study, to Julia Martin-Ortega and Klaus Glenk for providing feedback on an early version of this paper, and to two anonymous reviewers for their constructive criticism and suggestions.

Author Contributions: C.S. and A.A.R.I. jointly conceived the paper, planned the fieldwork strategy, and interpreted the results. C.S. carried out the fieldwork and analysed the interview data. C.S. wrote Sections 1 and 4-6; A.A.R.I. wrote Sections 2 and 3 (both authors provided input into all sections). C.S. and A.A.R.I. prepared and submitted the manuscript.

Conflicts of Interest: The authors declare no conflict of interest. The funding sponsors had no role in the design of the study; in the collection, analyses, or interpretation of the data; in the writing of the manuscript or in the decision to publish the results.

\section{References}

1. Alatout, S. Bringing Abundance into Environmental Politics: Constructing a Zionist Network of Water Abundance, Immigration, and Colonization. Soc. Stud. Sci. 2009, 39, 363-394. [CrossRef] [PubMed]

2. Erensü, S. Abundance and Scarcity amidst the Crisis of "Modern Water": The Changing Water-Energy Nexus in Turkey. In Contemporary Water Governance in the Global South: Scarcity, Marketization and Participation; Harris, L.M., Goldin, J.A., Sneddon, C., Eds.; Routledge: Abingdon, UK; New York, NY, USA, 2013; pp. 61-78, ISBN 978-0415657990.

3. Selby, J.; Hoffmann, C. Beyond scarcity: Rethinking water, climate change and conflict in the Sudans. Glob. Environ. Chang. 2014, 29, 360-370. [CrossRef]

4. Sprague, J.B. Great Wet North? Canada's Myth of Water Abundance. In Eau Canada: The Future of Canada's Water; Bakker, K., Ed.; UBC Press: Vancouver, BC, Canada, 2007; pp. 23-35, ISBN 978-0774813402.

5. Urteaga-Crovetto, P. Between Water Abundance and Scarcity: Discourses, Biofuels, and Power in Piura, Peru. Antipode 2016, 48, 1059-1079. [CrossRef]

6. Aitken, D.; Rivera, D.; Godoy-Faúndez, A.; Holzapfel, E. Water Scarcity and the Impact of the Mining and Agricultural Sectors in Chile. Sustainability 2016, 8, 128. [CrossRef]

7. Browne, A.L.; Dury, S.; de Boer, C.; la Jeunesse, I.; Stein, U. Governing for Drought and Water Scarcity in the Context of Flood Disaster Recovery: The Curious Case of Somerset, United Kingdom. In Governance for Drought Resilience: Land and Water Drought Management in Europe; Bressers, H., Bressers, N., Larrue, C., Eds.; Springer-Nature: Berlin, Germany, 2016; pp. 83-107, ISBN 978-3319296692.

8. Rijsberman, F.R. Water scarcity: Fact or fiction? Agric. Water Manag. 2006, 80, 5-22. [CrossRef]

9. Sapountzaki, K.; Daskalakis, I. Transboundary resilience: The case of social-hydrological systems facing water scarcity or drought. J. Risk Res. 2016, 19, 829-846. [CrossRef]

10. Seckler, D.; Barker, R.; Amarasinghe, U. Water Scarcity in the Twenty-first Century. Int. J. Water Resour. Dev. 1999, 15, 29-42. [CrossRef]

11. Shi, M.; Wang, X.; Yang, H.; Wang, T. Pricing or Quota? A Solution to Water Scarcity in Oasis Regions in China: A Case Study in the Heihe River Basin. Sustainability 2014, 6, 7601-7620. [CrossRef] 
12. Yang, W.; Song, J.; Higano, Y.; Tang, J. An Integrated Simulation Model for Dynamically Exploring the Optimal Solution to Mitigating Water Scarcity and Pollution. Sustainability 2015, 7, 1774-1797. [CrossRef]

13. Ávila-García, P. Hacia una ecología política del agua en Latinoamérica [Towards a Political Ecology of Water in Latin America]. Rev. Estud. Soc. 2016, 55, 18-31. [CrossRef]

14. Boelens, R.; Hoogesteger, J.; Swyngedouw, E.; Vos, J.; Wester, P. Hydrosocial territories: A political ecology perspective. Water Int. 2016, 41, 1-14. [CrossRef]

15. Johnston, B.R. The Political Ecology of Water: An Introduction. Capital. Nat. Social. 2003, 14, 73-90. [CrossRef]

16. Rodríguez-Labajos, B.; Martínez-Alier, J. Political ecology of water conflicts. Wiley Interdiscip. Rev. Water 2015, 2, 537-558. [CrossRef]

17. Ioris, A.A.R. Water reforms in Brazil: Opportunities and constraints. J. Environ. Plan. Manag. 2009, 52, 813-832. [CrossRef]

18. Ioris, A.A.R. The political nexus between water and economics in Brazil: A critique of recent policy reforms. Rev. Radic. Political Econ. 2010, 42, 231-250. [CrossRef]

19. Mena-Vásconez, P.; Vincent, L.; Vos, J.; Boelens, R. Fighting over water values: Diverse framings of flower and food production with communal irrigation in the Ecuadorian Andes. Water Int. 2017, 42, 443-461. [CrossRef]

20. Perreault, T. Dispossession by Accumulation? Mining, Water and the Nature of Enclosure on the Bolivian Altiplano. Antipode 2013, 45, 1050-1069. [CrossRef]

21. Renfrew, D. The Curse of Wealth: Political Ecologies of Latin American Neoliberalism. Geogr. Compass 2011, 5, 581-594. [CrossRef]

22. Swyngedouw, E. Modernity and Hybridity: Nature, Regeneracionismo, and the Production of the Spanish Waterscape, 1890-1930. Ann. Assoc. Am. Geogr. 1999, 89, 443-465. [CrossRef]

23. Ioris, A.A.R. The Positioned Construction of Water Values: Pluralism, Positionality and Praxis. Environ. Values 2012, 21, 143-162. [CrossRef]

24. Bisung, E.; Elliott, S.J.; Abudho, B.; Schuster-Wallace, C.J.; Karanja, D.M. Dreaming of toilets: Using photovoice to explore knowledge, attitudes and practices around water-health linkages in rural Kenya. Health Place 2015, 31, 208-215. [CrossRef] [PubMed]

25. Joy, K.J.; Kulkarni, S.; Roth, D.; Zwarteveen, M. Re-politicising water governance: Exploring water re-allocations in terms of justice. Local Environ. 2014, 19, 954-973. [CrossRef]

26. Bebbington, A.; Humphreys-Bebbington, D.; Bury, J. Federating and defending: Water, territory and extraction in the Andes. In Out of the Mainstream: Water Rights, Politics and Identity; Boelens, R., Getches, D., Guevara-Gil, A., Eds.; Earthscan: London, UK, 2010; pp. 307-328, ISBN 978-1849714556.

27. Biro, A. Half-Empty or Half-Full? Water Politics and the Canadian National Imaginary. In Eau Canada: The Future of Canada's Water; Bakker, K., Ed.; UBC Press: Vancouver, BC, Canada, 2007; pp. 321-333, ISBN 978-0774813402.

28. Brandes, O.M.; Kriwoken, L. Changing Perspectives-Changing Paradigms: Taking the "Soft Path" to Water Sustainability in the Okanagan Basin. Can. Water Resour. J. 2006, 31, 75-90. [CrossRef]

29. De Loë, R. A Canadian Vision and Strategy for Water in the 21st Century. Policy Options 2009, 30, 21-24.

30. Veiga, L.B.E.; Magrini, A. The Brazilian Water Resources Management Policy: Fifteen Years of Success and Challenges. Water Resour. Manag. 2013, 27, 2287-2302. [CrossRef]

31. Tao, W.; Tian, G. Analysis of Water Resource Curse in Heilongjiang Province. J. Chongqing Univ. Technol. (Nat. Sci.) 2015, 29, 103-107. [CrossRef]

32. Tate, D.M. Canadian Water Management: A One Armed Giant. Can. Water Resour. J. 1984, 9, 1-6. [CrossRef]

33. Colten, C.E. Southern Water: The Limits to Abundance; LSU Press: Baton Rouge, LA, USA, 2014; pp. 1-280, ISBN 978-0807156506.

34. Fiege, M. Irrigated Eden: The Making of an Agricultural Landscape in the American West; University of Washington Press: Seattle, WA, USA, 1999; pp. 1-320, ISBN 0295977574.

35. Abers, R.N.; Keck, M.E. Practical Authority: Agency and Institutional Change in Brazilian Water Politics; Oxford University Press: New York, NY, USA, 2013; pp. 1-288, ISBN 978-0199985272.

36. Empinotti, V.L. Politics of Scale and Water Governance in the Upper Xingu River Basin, Brazil. In Agriculture, Environment and Development: International Perspectives on Water, Land and Politics; Ioris, A.A.R., Ed.; Palgrave Macmillan: London, UK, 2016; pp. 197-219, ISBN 978-3319322544. 
37. Libanio, P.A.C. The use of goal-oriented strategies in the building of water governance in Brazil. Water Int. 2014, 39, 401-416. [CrossRef]

38. Martins, R.C. Boundaries between Inequality and Difference in Water Governance. Ambient. Soc. 2015, 18, 211-228. [CrossRef]

39. Van den Brandeler, F.; Hordijk, M.; von Schönfeld, K.; Sydenstricker-Neto, J. Decentralization, participation and deliberation in water governance: A case study of the implications for Guarulhos, Brazil. Environ. Urban. 2014, 26, 489-504. [CrossRef]

40. De Paes, R.P.; Brandão, J.L.B. Flood Control in the Cuiabá River Basin, Brazil, with Multipurpose Reservoir Operation. Water Resour. Manag. 2013, 27, 3929-3944. [CrossRef]

41. De Lima, C.R.N.; Zeilhofer, P.; Dores, E.; Fantin-Cruz, I. Variabilidade espacial da Qualidade de Água em Escala de Bacias—Rio Cuiabá e São Lourenço, Mato Grosso [Spatial Variability of Water Quality on a watershed scale-Cuiabá and São Lourenço river, Mato Grosso]. Rev. Bras. Recur. Hídricos 2015, 20, 169-178. [CrossRef]

42. Zeilhofer, P.; Lima, E.B.N.R.; Lima, G.A.R. Land use effects on water quality in the urban agglomeration of Cuiabá and Várzea Grande, Mato Grosso State, central Brazil. Urban Water J. 2010, 7, 173-186. [CrossRef]

43. Fantin-Cruz, I.; Pedrollo, O.; Girard, P.; Zeilhofer, P.; Hamilton, S.K. Effects of a diversion hydropower facility on the hydrological regime of the Correntes River, a tributary to the Pantanal floodplain, Brazil. J. Hydrol. (Amst.) 2015, 531, 810-820. [CrossRef]

44. Zeilhofer, P.; de Moura, R.M. Hydrological changes in the northern Pantanal caused by the Manso dam: Impact analysis and suggestions for mitigation. Ecol. Eng. 2009, 35, 105-117. [CrossRef]

45. Alves, É.C.R.F.; de Oliveira Silvino, A.N.; de Andrade, N.L.R.; Silveira, A. Gestão dos Recursos Hídricos no Estado de Mato Grosso [Water Resources Management in the State of Mato Grosso]. Rev. Bras. Recur. Hidricos 2009, 14, 69-80. [CrossRef]

46. Ioris, A.A.R. Rethinking Brazil's Pantanal Wetland: Beyond Narrow Development and Conservation Debates. J. Environ. Dev. 2013, 22, 239-260. [CrossRef]

47. Ioris, A.A.R. Water challenges in the Pantanal: Old problems in new economic frontiers. Geographer (RSGS) 2016, Spring, 26-27.

48. Lucidio, J.A.B. 'A Ocidente do Imenso Brasil': As Conquistas dos Rios Paraguai e Guaporé (1680-1750) [To the West of the Immense Brazil: The Conquests of the Rivers Paraguay and Guapore (1680-1750)]. Ph.D. Thesis, Universidade Nova de Lisboa, Lisbon, Portugal, July 2013.

49. Ricardo, C. Marcha para o Oeste [March towards the West], 4th ed.; Livraria José Olympio: Rio de Janeiro, Brazil, 1970; pp. 1-681.

50. Siqueira, E.M. História de Mato Grosso: Da Ancestralidade aos Dias Atuais [History of Mato Grosso: From Ancient Times to the Present Day]; Entrelinhas: Cuiabá, Brazil, 2002; pp. 1-272, ISBN 8587226142.

51. Cabeza de Vaca, A.N. Naufragios y Comentarios [Shipwrecks and Commentaries]; Calpe: Madrid, Spain, 1922; pp. 1-368.

52. Bethell, L. The Paraguayan War (1864-1870); Institute of Latin American Studies, University of London: London, UK, 1996; pp. 1-41, ISBN 1900039087.

53. Martins, L. A "Tropical Papageno": Claude Lévi-Strauss and Roberto Ipureu in Mato Grosso, Brazil. In Agents of Transculturation: Border-Crossers, Mediators, Go-Betweens; Jobs, S., Mackenthun, G., Eds.; Waxmann Verlag GmbH: Münster, Germany, 2013; pp. 281-310, ISBN 978-3830930020.

54. Barrozo, J.C. A Questão Agrária em Mato Grosso: A Persistência da Grande Propriedade [The Agrarian Question in Mato Grosso: The Persistence of the Large Property]. In Mato Grosso: A (Re)Ocupação da Terra na Fronteira Amazônica (Século XX) [Mato Grosso: The (Re)Occupation of Land in the Amazonian Frontier (20th Century)]; Barrozo, J.C., Ed.; Editora Unisinos, Oikos: São Leopoldo, Brazil; EdUFMT: Cuiabá, Brazil, 2010; pp. 11-27, ISBN 978-8578431570.

55. Da Cunha, J.M.P. Dinâmica migratória e o processo de ocupação do Centro-Oeste brasileiro: O caso de Mato Grosso [Migratory dynamics and the occupation process in central-western Brazil: The case of the State of Mato Grosso]. Rev. Bras. Estud. Popul. 2006, 23, 87-107. [CrossRef]

56. Wilcox, R. Cattle and Environment in the Pantanal of Mato Grosso, Brazil, 1870-1970. Agric. Hist. 1992, 66, 232-256. 
57. Ioris, A.A.R. Controversial Frontiers of Agricultural Development and Environmental Change. In Agriculture, Environment and Development: International Perspectives on Water, Land and Politics; Ioris, A.A.R., Ed.; Palgrave Macmillan: London, UK, 2016; pp. 221-250, ISBN 978-3319322544.

58. Dos Santos, D.A.; Marta, J.M.C. A Lei Kandir e o desenvolvimento de Mato Grosso: Análise do período 1990-2009 [The Kandir Law and the development of Mato Grosso: Analysis of the period 1990-2009]. Rev. Bras. Gest. Desenvolv. Reg. 2014, 10, 206-228.

59. Laval, E. Luttes au sein du régime alimentaire néolibéral: Résistance et émergence politique des producteurs de soja du Mato Grosso [Struggles within the neoliberal food regime: Resistance and political emergence of the soybean producers of Mato Grosso]. Can. J. Dev. Stud. 2015, 36, 296-312. [CrossRef]

60. Peine, E.K. Trading on Pork and Beans: Agribusiness and the Construction of the Brazil-China-Soy-Pork Commodity Complex. In The Ethics and Economics of Agrifood Competition; The International Library of Environmental, Agricultural and Food Ethics 20; James, H.S., Jr., Ed.; Springer Science + Business Media: Dordrecht, The Netherlands, 2013; pp. 193-210, ISBN 978-9400762732.

61. Wilkinson, J.; Wesz Junior, V.J.; Lopane, A.R.M. Brazil and China: The agribusiness connection in the Southern Cone context. Third World Themat. 2016, 1, 726-745. [CrossRef]

62. Secretaria de Estado do Meio Ambiente (SEMA). Plano Estadual de Recursos Hídricos de Mato Grosso (PERH-MT) [Mato Grosso State Water Resources Plan]; KCM Editora: Cuiabá, Brazil, 2009; pp. 1-184, ISBN 978-8577690718.

63. Calheiros, D.F.; de Oliveira, M.D.; Padovani, C.R. Hydro-ecological Processes and Anthropogenic Impacts on the Ecosystem Services of the Pantanal Wetland. In Tropical Wetland Management: The South-American Pantanal and the International Experience; Ioris, A.A.R., Ed.; Ashgate: Farnham, UK, 2012; pp. 29-57, ISBN 978-1409418788.

64. Figueiredo, D.M.; Dores, E.F.G.C.; Paz, A.R.; Souza, C.F. Availability, Uses and Management of Water in the Brazilian Pantanal. In Tropical Wetland Management: The South-American Pantanal and the International Experience; Ioris, A.A.R., Ed.; Ashgate: Farnham, UK, 2012; pp. 59-98, ISBN 978-1409418788.

65. Junk, W.J.; Nunes da Cunha, C. Wetland Management Challenges in the South-American Pantanal and the International Experience. In Tropical Wetland Management: The South-American Pantanal and the International Experience; Ioris, A.A.R., Ed.; Ashgate: Farnham, UK, 2012; pp. 315-331, ISBN 978-1409418788.

66. Schulz, C.; Ioris, A.A.R.; Martin-Ortega, J.; Glenk, K. Prospects for Payments for Ecosystem Services in the Brazilian Pantanal: A Scenario Analysis. J. Environ. Dev. 2015, 24, 26-53. [CrossRef]

67. Leifeld, P. Discourse Networks and German Pension Politics. Ph.D. Thesis, University of Konstanz, Constance, Germany, 2011.

68. Euzen, A.; Morehouse, B. Water: What values? Policy Soc. 2011, 30, 237-247. [CrossRef]

69. Schulz, C.; Martin-Ortega, J.; Glenk, K.; Ioris, A.A.R. The Value Base of Water Governance: A Multi-Disciplinary Perspective. Ecol. Econ. 2017, 131, 241-249. [CrossRef]

70. De Arruda Filho, V.F. Mato Grosso: Estado das águas recebe o XIV ENCOB [Mato Grosso: State of the waters hosts the 14th National Meeting of River Basin Committees (ENCOB)]. Águas do Bras. 2013, 5, 4-7.

71. Hoelle, J.A. Cattle Culture in Amazonia: The Rise of Ranching in Acre, Brazil. Ph.D. Thesis, University of Florida, Gainesville, FL, USA, 2011.

72. Organisation for Economic Co-operation and Development (OECD). Water Resources Governance in Brazil; OECD Studies on Water; OECD Publishing: Paris, France, 2015; pp. 1-280, ISBN 978-9264238114.

73. Brea, M.; Zucol, A.F. The Paraná-Paraguay Basin: Geology and Paleoenvironments. In Historical Biogeography of Neotropical Freshwater Fishes; Albert, J.S., Reis, R.E., Eds.; University of California Press: Berkeley, CA, USA; Los Angeles, CA, USA; London, UK, 2011; pp. 69-87, ISBN 978-0520268685.

74. Loureiro, R. Cultura Mato-Grossense: Festas de Santos e Outras Tradições [Mato Grosso's Culture: Festivals of the Saints and Other Traditions]; Entrelinhas: Cuiabá, Brazil, 2006; pp. 1-239, ISBN 8587226533.

75. Santos, G.L.d.S. O Siriri na Contemporaneidade em Mato Grosso: Suas Relações e Trocas [The Siriri [Dance] in Mato Grosso Today: Its Relations and Transformations]. Master's Thesis, Federal University of Mato Grosso (UFMT), Cuiabá, Brazil, 2010.

76. Sousa, I. CAB Cuiabá é campeã de reclamações no Procon-MT: Empresa de água e esgoto supera Sanecap em cobrança indevida e falta d'água [CAB Cuiabá is the champion of complaints with Procon-MT: Water and sanitation company surpasses Sanecap with erroneous charges and lacking water]. MidiaNews, 9 April 2014. 
77. Empresa Dona da CAB Cuiabá Deve ir a Leilão Judicial Nesta Quinta-Feira [The Company Owning CAB Cuiabá Has to go to a Bankruptcy Auction This Thursday]. Available online: http:/ /g1.globo.com/matogrosso/noticia/2015/12/empresa-dona-da-cab-cuiaba-deve-ir-leilao-judicial-nesta-quinta-feira.html (accessed on 19 September 2017).

78. Prefeitura de Cuiabá Troca Grupo que Administra Serviço de Água e Esgoto [The Municipal Administration of Cuiabá Changes the Water and Sanitation Service Provider]. Available online: http:/ /g1.globo.com/mato-grosso/noticia/2016/11/prefeitura-de-cuiaba-troca-grupo-que-administraservico-de-agua-e-esgoto.html (accessed on 19 September 2017).

79. Ioris, A.A.R. Encroachment and entrenchment of agro-neoliberalism in the Centre-West of Brazil. J. Rural Stud. 2017, 51, 15-27. [CrossRef]

80. Schulz, C.; Martin-Ortega, J.; Ioris, A.A.R.; Glenk, K. Applying a 'Value Landscapes Approach' to Conflicts in Water Governance: The Case of the Paraguay-Paraná Waterway. Ecol. Econ. 2017, 138, 47-55. [CrossRef]

81. Candler, G.G. Particularism versus Universalism in the Brazilian Public Administration Literature. Public Adm. Rev. 2002, 62, 298-306. [CrossRef]

82. Ioris, A.A.R. Latin America's Large-Scale Urban Challenges: Development Failures and Public Service Inequalities in Lima, Peru. ACME 2015, 14, 1161-1186.

83. Da Silva, C.J.; Albernaz-Silveira, R.; Nogueira, P.S. Perceptions on climate change of the traditional community Cuiabá Mirim, Pantanal Wetland, Mato Grosso, Brazil. Clim. Chang. 2014, 127, 83-92. [CrossRef]

84. Ioris, A.A.R. The Production of Poverty and the Poverty of Production in the Amazon: Reflections from Those at the Sharp End of Development. Capital. Nat. Social. 2015, 26, 176-192. [CrossRef]

(C) 2017 by the authors. Licensee MDPI, Basel, Switzerland. This article is an open access article distributed under the terms and conditions of the Creative Commons Attribution (CC BY) license (http:// creativecommons.org/licenses/by/4.0/). 